\title{
POSITIVISASI HUKUM PIDANA ISLAM (Analisis atas Qanun No: 14/2003 Tentang Khalwat/Mesum Provinsi Nangroe Aceh Darussalam)
}

\author{
Ridwan \\ STAIN Purwokerto \\ Jl. Jend. Ahamd Yani No. 40 A Purwokerto \\ Email: ridwanparadise@yahoo.com
}

\begin{abstract}
Abstrak
Pelaksanaan syari'at Islam di Nanggroe Aceh Darussalam merupakan refleksi dari aspirasi mayoritas masyarakat Aceh. Penerapan qanun khalwat di Nangroe Aceh Darussalam adalah bagian dari upaya positivisasi hukum Islam dalam sistem hukum nasional.Tujuan diberlakukanya qanun khalwat adalah terciptanya tatanan moral yang berbasis pada moral hukum Islam dalam bentuk regulasi yang penegakkannya melalui institusi formal yang disebut dengan Mahkamah Syari'ah. Substansi hukum materiil qanun khalwat adalah perpaduan antara hukum Islam, hukum nasional dan nilai-nilai lokal masyarakat Aceh. Konsekuensinya adalah berbagai qanun pidana termasuk qanun khalwat yang lahir di Aceh memiliki derajat keragaman bahkan ada disparitas antara hukum materiil qanun dengan konsep hukum pidana dalam fikih.
\end{abstract}

Kata kunci: positivisasi, qanun khalwat, hukum pidana Islam, hukum pidana nasional, Nangroe Aceh Darussalam

\begin{abstract}
The implementation of Islamic law (syari'ah) in Nanggroe Aceh Darussalam reflects the aspiration of its social majority. The implementation of qanun khalwat is one example of formalizing Islamic law to national law system. The aims of qanun khalwat is the realization of moral system based on Islamic law moral and it is realized in the regulation for its obedience through formal institution called Mahkamah Syariah. The substance of material law of qanun khalwat is the combination of Islamic law, national law, and Aceh local wisdom. Consequently, there are various criminal qanun, including qanun khalwat that have the degree of variety and even disparity between material law of qanun and the concept of criminal law in fiqh.
\end{abstract}

Keywords: formalizing, qanun khalwat, Islamic criminal law, national criminal law, Nangroe Aceh Darussalam

\section{A. Pendahuluan}

Sebagai negara yang multi etnik, agama, ras dan budaya, Indonesia dipersatukan dalam keseragaman dengan semboyan Bhineka Tunggal Ika. Namun demikian, ikatan persatuan dengan semboyan tersebut bukan berarti mudah dipersatukan khususnya berkaitan dengan pergulatan politik hukum baik pada tataran lokal maupun nasional. Pluralisme dan dualisme hukum sering mengemuka dan menjadi salah satu fenomena pluralitas orientasi kebangsaan terutama dengan munculnya semangat menonjolkan politk 'aliran' atau 'identitas' yang dibingkai dengan semangat 
keberagamaan. Dalam proses pertarungan ruang dominasi hukum ini, secara kategoris dapat dipetakan menjadi tiga kelompok. Pertama, kelompok pembela hukum adat. Kedua, pembela hukum Islam. Ketiga pembela hukum warisan kolonial Belanda. ${ }^{1}$

Akar sejarah formalisasi syariat Islam dalam konteks keindonesiaan bukanlah barang baru. Bagi pendukung penegakkan syari'at Islam menyatakan bahwa pemberlakukan syari'at Islam mempunyai dasar pijakan sejarah yang kuat baik secara filosofis maupun histories. Bukti historis tersebut antara lain terekam dalam buku Mr. Lodewijk Willem Van der Berg yang berjudul Muhammadansch Recht yang menuliskan pemberlakukan syariat Islam di bumi Nusantara jauh sebelum Belanda datang yang pada waktu itu umat Islam diketahui menganut mazhab Hanafi dan Syafi'i. ${ }^{2}$

Syariat Islam bagi kelompok pengusungnya adalah solusi atas berbagai problematika sosial. Dengan syari'at Islam, manusia mampu mengeluarkan dirinya dari kubangan kemiskinan, baik kemiskinan struktural maupun kultural. Dengan basis ajaranya sebagai rahmatan lil alamin Islam bisa menawarkan sistem yang berpijak pada prinsip tidak membuat seseorang menjadi rugi ataupun merugikan orang lain.

Derasnya gagasan formalisasi syari'at Islam di Indonesia dalam beberapa tahun terakhir disebabkan antara lain oleh tiga hal. Pertama, adanya upaya sebagian partai politik Islam seperti Partai Persatuan Pembangunan (PPP) dan Patai Bulan Bintang (PBB) pada sidang Tahunan MPR tahun 2002 untuk mengamandeman Pasal 29 UUD 1945 dengan memasukan tujuh kata (dengan kewajiban menjalankan syari'at Islam bagi pemeluk-pemeluknya) dalam Piagam Jakarta sebagai landasan konstitusional. Kedua, adanya formalisasi ajaran Islam oleh unsur birokrat di beberapa daerah seperti di NAD, Kabupaten Cianjur dan Tasikmalaya
Jawa Barat. Ketiga, maraknya seruan atau kampanye memformalisasikan syari'at Islam dalam seluruh aspek kehidupan sebagaimana dilakukan antara lain oleh Hizbut Tahrir, Front Pembela Islam dan Majelis Mujahidin Indonesia. ${ }^{3}$

Dalam konteks perkembangan kebijakan desentralisasi oleh pemerintah Pusat dengan memberikan wewenang lebih kepada daerah melalui berbagai paket regulasi otonomi daerah, telah memunculkan perkembangan menarik terkait dengan tuntutan pemberlakuan hukum agama (syariat Islam) di berbagai daerah. Salah satu daerah provinsi yang secara tegas mendeklarasikan dirinya sebagai daerah yang memberlakukan syariat Islam adalah Provinsi Nangroe Aceh Darussalam (NAD). ${ }^{4}$

Dalam kaitannya dengan pemberian otonomi daerah khusus kepada NAD, pemerintah pusat telah membuat berbagai paket ragulasi antara lain UU No. 44 Tahun 1999 tentang Penyelenggaran Keistimewaan Provinsi Daerah Istimewa Aceh. Pemberlakuan UU tersebut disambut dengan gembira oleh masyarakat Aceh sehingga lahirlah berbagai Peraturan Daerah (Perda) seperti Perda No. 3 Tahun 2000 tentang Mejelis Permusyawaratan Ulama, Perda No. 5 Tahun 2000 tentang Pelaksanaan Syari'at Islam dan Perda No. 7 tahun 2000 tentang Penyelenggaraan Kehidupan Adat. Untuk mempertegas posisi Provinsi Aceh sebagai daerah istimewa dengan corak khas Islam, Pemerintah Pusat kemudian mengeluarkan UU No. 18 tahun 2001 Tentang Provinsi Nangroe Aceh Darusalam yang mengatur lebih detail persoalan Mahkamah Syar'iyah, qānūn, lambang daerah, zakat sebagai pemasukan daerah dan masalah kepemimpinan adat. ${ }^{5}$

Dalam kaitan dengan implementasi syari'at Islam khususnya dalam bidang hukum pidana, terdapat tiga qanun yng berjalan efektif yaitu qanun No. 12 Tahun 2003 tentang Minuman Khamer dan sejenisnya, Qanun 
No. 13 tahun 2003 tentang Maisir (Perjudian) dan Qanun No. 14 tahun 2003 tentang Mesum (khalwat). Ketiga qanun ini termasuk dalam bidang kajian hukum pidana Islam atau yang dalam istilah fikih disebut dengan fiqh Jin ayah. Pada tataran implementasi Perda Syariah (qanun) lembaga yang diberi mandat untuk melakukan pengawasan bagi implementasi syari'at Islam adalah Dinas Syari'ah / Wilayatul Hisbah.

Dalam konteks hukum Islam, ketiga qanun tersebut di atas termasuk dalam kategori jarimah ${ }^{6}$ hudùd dan ta'zir. ${ }^{7}$ Hukuman atas tindak pidana dapat dikategorikan menjadi empat bagian. Pertama, hukuman fisik yang meliputi hukuman potong tangan, hukuman cambuk dan rajam. Kedua, membatasi kebebasan seperti hukuman penjara atau mengasingkan narapidana. Ketiga, membayar denda. Keempat, peringatan yang diberikan oleh hakim. Tindak pidana bezina dan mengkonsumsi barang yang memabukkan termasuk dalam kategori hudūd. Pidana zina dirajam sampai mati atau dicambuk seratus kali. Sedangkan mengkonsumsi sesuatu yang memabukan diancam hukuman cambuk sebanyak delapanpuluh kali. Para ulama fikih memasukan tindak pidana khalwat atau mesum ke dalam kelompok pidana ta'zir dengan mendasarkan pada hadis yang secara tegas mengharamkan perbuatan khalwat. ${ }^{8}$

Adapun terkait dengan pelaksana dari penegakan hukuman bagi pelaku tindak pidana adalah pemerintah atau ulil amr sebagai bagian dari penegakan amar ma'ruf nahi munkar. Pemidanaan atas pelaku pelanggaran ditegakkan sebagai perimbangan atas meninggalkan kewajiban-kewajiban hukum dan meninggalkan sesuatu yang dilarang. Otoritas pemerintah dalam memberikan hukuman dalam bentuk ta'zir besar kecilnya sanksi pidana ditentukan oleh besar kecilnya pelanggaran. Para ulama berbeda pendapat dalam hal menentukan banyaknya ta'zir dalam bentuk cambuk.
Pertama, ulama yang mengatakan sepuluh kali cambukan, kedua, berpendapat tigapuluh sembilan kali dan ada yang berpendapat empat puluh sembilan kali cambukan seperti pendapat ulama mazhab Hanafi dan Syafi'i. Ketiga, berpendapat bahwa jumlah hukuman cambuk tidak ada ketentuan pastinya dan ini adalah pendapat ulama mazhab Malik dan sebagian ulama mazhab Syafi'i dan Ahmad.

Dengan mendasarkan pada peta pendapat ulama mazhab terkait dengan konsep pemidanaan/kriminalisasi atas pelaku tindak pidana khalwat (mesum) kemudian didialogkan dengan ketentuan fikih Islam menjadi menarik untuk dikaji. Fokus studi diarahkan pada rumusan konseptual dari tindak pidana dan pemidanaanya serta pada pencarian landasan metodologis perumusannya sebagai ikhtiar pengembangan pemikiran hukum pidana Islam (fiqh jinàyah) dalam konteks keindonesiaan.

\section{B. Sketsa Historis Pemberlakuan Syariat Islam Di Provinsi NAD}

Setelah Indonsia merdeka, Aceh menjadi bagian dari Negara Kesatuan Republik Indonesia. Konsekuensi yuridisnya adalah Aceh harus tunduk pada sistem hukum yang berlaku di negara kesatuan Indonesia. Institusi hukum adat dan hukum Islam dijalankan oleh lembaga peradilan negeri. Dalam posisi demikian, uleebalang tidak lagi fungsional karena tergantikan oleh sistem hukum peradilan negara. Puncak dari kekecewaan pereduksian pemberlakuan syari'at Islam di Aceh ditandai dengan munculnya gerakan Darul Islam yang dipelopori oleh Teungku Muhammad Daud Beureueh. Pada bulan september 1953, Teungku Muhammad Daud Beureueh menyatakan bahwa daerah Aceh dan daerah yang berbatasan dengannya menjadi bagian dari negara Islam Indonesia di bawah pimpinan Kartosuwiryo dan tidak mengakui kepemimpinan nasional Indonesia. 
Pada tahun 1959, pemerintah pusat dalam kerangka mendukung pemberlakuan syariat Islam, Aceh ditetapkan sebagai daerah istimewa melalui Keputusan Perdana Menteri RI, No:1 / Missi/1959. Keputusan pemerintah yang menyatakan bahwa Aceh sebagai daerah istimewa. Keistimewaan Aceh atas daerah lain di Indonesia adalah pemberlakuan syari'at Islam. Pada tahun 1963, DPRD menetapkan Perda No: 01 Tahun 1963 tentang pelaksanaan syiar Islam. Dalam perkembangannya, Perda ini kemudian ditolak oleh pemerintah pusat melalui Keputusan Menteri Dalam Negeri. Politik formalisasi syariat Islam di Aceh kembali mengalami kegagalan.

Reformasi membuka jalan bagi rakyat Aceh untuk kembali menuntut pemberlakuan syari'at Islam, sesuai dengan keistimewaan Aceh bahkan referendum. Dalam kenyataannya, tuntutan referendum bagi Aceh mendominasi tuntutan pemberlakuan syari'at Islam. Pada 13 Januari 1999, Angkatan Intelektual Darussalam mengeluarkan pernyataan politik yang menghimbau dilaksanakanya referendum di Aceh untuk menyelesaikan konflik. Demikian pula tuntutan yang sama diajukan berdasarkan hasil kongres mahasiswa dan pemuda Aceh Serantau yang diadakan di Banda Aceh pada 31 Januari dan 4 Februari 1999.

Respon Pemerintah Pusat dengan kuatnya tuntutan masyarakat Aceh akan pemberlakuan syari'at Islam adalah dengan mengundangkan UU No. 44 / 1999 tentang Penyelenggaraan Keistimewaan provinsi Daerah Istimewa Aceh, yang bermula dari pengajuan usul inisiatif sejumlah anggota DPR asal Aceh. Berpijak UU No. 44/1999, serangkaian Peraturan Daerah seperti Peraturan Daerah No. 3/2000 tentang Majelis Permusyawaratan Ulama diundanglan pasa tanggal 22 Juni 2000, Peraturan Daerah No. 5/2000 tentang Pelaksanaan Syari'at Islam yang diundangkan pada 25 Agustus 2000.
Kebijakan Pemerintah Pusat selanjutnya adalah dikeluarkannya UU No. 18/2001 tentang Provinsi Nanggroe Aceh Darussalam (NAD) yang mengatur lebih jauh otonomi khusus bagi NAD, seperti Mahkamah Syar'iyyah, Qanun, lambang daerah, zakat sebagai pemasukan daerah, kepolisian dengan ciri khas Aceh, kepemimpinan adat dan lainnya. Dari UU tentang NAD inilah kemudian lahir berbagai instrumen hukum lainnya dalam bentuk qanun sebagai bagian dari implementasi pemberlakuan syari'at Islam secara kaffah. ${ }^{9}$ Penyediaan instrumen birokrasi sebagai pelaksana sekaligus sebagai pengawas pemberlakukan syari'at Islam adalah terbitnya Peraturan Daerah No. 33/2001 tentang Dinas Syari'at.

Dinas Syari'at bertugas sebagai penaggungjawab perencanaan dan pelaksanaan syari'at Islam di NAD, terutama dalam kaitannya dengan penyiapan rancangan qanun pengamalan syari'at Islam, pembentukan mahkamah syari'at di seluruh Aceh, penyiapan tenaga dan saranya, membantu dan menata penyelenggaraan tempat peribadatan, mengawasi pelaksanaan syari'at Islam serta memberi bimbingan dan penyuluhan tentangnya.

Pelaksanaan syari'at Islam di NAD dalam konteks perundang-undangan mengacu pada dasar negara Indonesia yang berdasar Ketuhanan Yang Maha Esa sebagaimana dalam Pasal 29 UUD 1945. Dengan kata lain, penerapan syari'at Islam dalam konteks yuridis formal tidak bertentangan, apalagi NAD sebagai salah satu daerah istimewa yang pasti mempunyai karakteristik berbeda dengan daerah lainnya. Diberlakukannya Peraturan Daerah No. 5/2000 tentang Pelaksanaan Syari'at Islam yang diundangkan pada 25 Agustus 2000 merupakan dukungan yuridis bagi rakyat Aceh untuk melaksanakan syari'at Islam sebagai hukum dalam kehidupan seharihari. 
Nilai istimewa sekaligus sebagai kekhususan NAD antara lain dapat dilihat dari adanya Mahkamah Syar'iyyah, Qanun Provinsi NAD, lambang daerah, zakat sebagai pemasukan daerah, kepolisian dengan ciri khusus dan lain sebagainya.

Dalam Pasal 1 ayat (7) UU NAD dinyatakan :

Mahkamah Syar'iyyah Provinsi NAD adalah lembaga peradilan yang bebas dari pengaruh manapun dalam wilayah Provinsi NAD yang berlaku untuk pemeluk agama Islam.

Selanjutnya pasal 25 ayat (1), (2)

dan (3) menjelaskan :

(1) Peradian syari'at Islam di Provinsi NAD sebagai bagian dari sistem peradilan nasional yang dilakukan oleh mahkamah syar'iyyah yang bebas dari pengaruh pihak manapun.

(2) Kewenangan Mahkamah Syar'iyyah sebagaimana dimaksud pada ayat (1) didasarkan atas syari'at Islam dalam sistem hukum nasional, yang diatur lebih lanjut dengan Qanun Provinsi Aceh.

(3) Kewenangan sebagaimana dimaksud ayat (2) diberlakukan bagi pemeluk agama Islam.

Jika Mahkamah Syar'iyyah merupakan lembaga yang diberi wewenang memeriksa dan memutus perkara terhadap pelanggaran syari'at Islam, maka hukum materiil dari syari'at Islam dijabarkan oleh Qanun yang dirumuskan oleh Dewan Perwakilan rakyat Aceh. Oleh karena itu perkembangan lahirnya berbagai qanun merupakan bagian dari pelaksanaan penerapan sayari'at Islam secara kaffah.

Pengadilan Agama (PA) di NAD pada awal tahun 2003 dikonversi menjadi Mahkamah Syar'iat. Mahkamah Syar'iyyah tingkat pertama ada di Kabupaten/Kota dan Mahkamah Syar'iyyah tingkat banding hanya ada di ibukota provinsi NAD. Sedangkan Mahkamah Syar'iyyah tingkat kasasi berada pada Mahkamah Agung (MA) RI di Jakarta. Mahkamah Syar'iyyah sebagaimana dinyatakan dalam salah satu Qanun Provinsi NAD bahwa Mahkamah Syar'iyyah adalah pengembangan dari Pengadilan Agama yang sudah ada. Dengan demikian, ada dua bentuk hukum positif yang akan diberlakukan di Mahkamah Syar'iyyah di Aceh. Pertama adalah peraturan perundang-undangan syari'at Islam yang berlaku secara nasional seperti sekarang diterapkan di Pengadilan Agama (PA) dengan kompetensi bidang hukum perkawinan, kewarisan dan perwakafan. ${ }^{10}$

Pemberlakuan syariat Islam di NAD juga dibarengi dengan lahirnya Peraturan Daerah No. 3 / 2000 tentang Majelis Permusyawaratan Ulama (MPU). Lembaga ini merupakan lembaga ulama independen yang dibentuk pada tingkat provinsi dan kabupaten serta bertugas memberikan masukan, pertimbangan, bimbingan dan nasihat serta saran dalam penentuan kebijakan daerah mengenai syari'at Islam. Fungsi MPU adalah menetapkan fatwa hukum, memberikan pertimbangan terhadap kebijakan daerah di bidang pemerintahan, pembangunan dan pembinaan masyarakat serta tatanan ekonomi yang islami.

Peraturan Daerah lain terkait dengan pemberlakuan syari'at Islam adalah Perda No. 5 / 2000 tentang Pelaksanaan Syari'at Islam. Perda ini hakikatnya menyempurnakan Perda No. 6/1968 tentang ketentuan Pokok-pokok Pelaksanaan Unsur-unsur Syari'at Islam. Aspek syari'at Islam yang dicakup dalam Perda ini adalah akidah, ibadah, muamalah, ahlak, pendidikan, dan dakwah islamiyah/ amar ma'rüf nahi munkar, baitul mal, kemasyarakatan, syiar Islam, pembelaan Islam, qadha, jinayat, munakahat, dan mawaris.

Ketentuan delik pidana kurungan 3 bulan atau denda 2 juta rupiah ditetapkan untuk pelanggaran terhadap ketentuanketentuan tertentu. Pasal 4 ayat (1) kewajiban menjalankan syari'at secara käffah. Pasal 4 ayat (3) kewajiban 
menghormati syari'at Islam bagi non Aceh. Pasal 8 ayat (2) kewajiban muslim menunda/menghentikkan segala kegiatan pada waktu tertentu untuk melaksanakan ibadah. Pasal 8 ayat (4) larangan bagi non muslim mengganggu ketenangan pelaksanaan ibadah. Pasal 15 ayat (3) kewajiban mengenakan busana muslimah dalam kehidupan privat dan publik.

Landasan yuridis yang mengatur lembaga peradilan yang mengawal berlakunya syari'at Islam adalah diundangkannya Qanun No. 10 / 2002 tentang Peradilan Syari'at Islam. Dalam Qanun tersebut dijelaskan tentang kewenangan mahkamah syari'ah. Di kalangan tokoh-tokoh Aceh, eksistensi Mahkamah Syar'iyyah dalam kaitan dengan hubungannya dengan peradilan lain masih menjadi perdebatan.

Mahkamah dalam bahasa Arab berarti pengadilan dan Syar'iyyah berarti syari'at. Dengan demikian, mahkamah syar'iyyah adalah pengadilan syari'at, atau pengadilan berdasarkan syari'at. Mahkamah Syar'iyyah adalah kata lain untuk menunnjukan Pengadilan Islam yang sudah ada di Indonesia sebelum kedatangan bangsa Barat. Berdasarkan Staatsblad No. 152 tahun 1882, pengadilan Islam disebut dengan nama salah satu, yaitu Priesteraad atau Rad Agama atau Landrat Agama dan selanjutnya menjadi pengadilan agama.

Paling tidak ada dua skenario pengembangan Mahkamah Syar'iyyah. Pertama, menjadikan Mahkamah Syar'iyyah sebagai badan peradilan tersendiri di luar Peradilan Agama dan Pengadilan Tinggi Agama. Dengan demikian, Mahkamah Syar'iyyah menjadi lembaga peradilan yang kelima setelah Peradilan Umum, Militer, Tata Usaha Negara dan Peradilan Agama. Kedua, menjadikan Mahkamah Syar'iyyah sebagai pengembangan dari Peradilan Agama dan Peradilan Tinggi Agama. Dengan kata lain Mahkamah Syar'iyyah adalah Pengadilan Agama yang diperluas wilayah kompetensinya, yakni berwenang mengadili perkara jināyah (hukum pidana Islam).

Pilihan salah satu skenario di atas mengandung konsekuensi tersendiri. Dalam Peraturan Daerah Provinsi Daerah Istimewa Aceh Nomor 5 Tahun 2000 tentang Pelaksanaan Syari'at Islam pasal 5 ayat (1) dinyatakan bahwa "untuk mewujudkan keistimewaan Aceh di bidang penyelenggaraan kehidupan beragama, setiap orang atau badan hukum yang berdomisili di daerah, berkewajiban menjunjung tinggi pelaksanaan syari'at Islam."

Dalam pandangan Bagir Mannan, Mahkamah Syar'iyyah merupakan bagian dari sistim peradilan nasional. Oleh karena itu, pengaturan-pengaturan hukumnya harus sesuai dengan hukum yang berlaku di negara Indonesia. Pelaksanaan Syari'at Islam tidak boleh mengganggu hak-hak warga non muslim. $^{11}$

Adapun ruang lingkup pelaksanaan syari'at Islam meliputi: (1) akidah, (2) ibadah, (3) muamalah, (4) akhlak, (5) pendidikan, dakwah islamiyah, amar makruf nahi munkar, (6) baitul mal, (7) kemasyarakatan, (8) syi'ar Islam, (9) pembelaan Islam, (10) qadla, (11) jinayat, (12) munakahat, (13) mawaris .

Ruang lingkup pemberlakuan syari'at Islam sebagaimana disebutkan di atas sesungguhnya masih menyisakan problematika pemaknaan, apa yang disebut dengan syari'at Islam. Dalam perkembangannya, pemaknaan terhadap syari'at Islam melahirkan tiga pengertian. Pertama, syari'at sebagai keseluruhan ajaran agama yang dibawa oleh Nabi Muhammad. Kedua, keseluruhan nash (al-nusuusus) al-Qur'an dan sunnah yang merupakan ajaran agama yang bersumber pada ucapan, perbuatan ataupun penetapan Nabi. Ketiga, pemahaman para ahli terhadap hukum yang berasal dari wahyu Allah melalui proses ijtihad. Pamaknaan syari'at yang ketiga ini hakikatnya adalah fikih. Dengan kata lain, syari'at yang dimaksud dalam 
pemaknaan sehari-hari adalah fikih itu sendiri, dan pamaknaan ini yang hakikatnya digunakan dalam memaknai istilah syari'at. $^{12}$

Pemaknaan syari'at dalam pengertian fikih kaya akan wawasan, cara pandang dan variasi pemahaman akan hukum. Ketika syari'at islam akan dilakukan positivasi dalam ranah hukum publik negara, maka syari'at Islam membutuhkan formulasi dalam bentuk kode hukum.

Islam sebagai sumber inspirasi pengembangan hukum bersumber dari alQur'an dan Hadis yang kemudian dikembangkan lebih lanjut oleh para mujtahid. Hukum Islam dalam pengertian umum masih dipandang oleh masyarakat sebagai primary rules yang dipandang sebagai sebuah kumpulan norma atau aturan yang berisikan perintah dan larangan dalam masyarakat. Normanorma ini menjadi hukum setelah diakui oleh negara sebagai aturan hukum resmi yang mengikat, mempunyai sistem peradilan untuk menjalankannya, dan kemungkinan adanya revisi serta penyempurnaan sesuai dengan tuntutan situasi dan kondisi.

Dengan mendasarkan pada cara berpikir di atas, posisi kekuasaan politik / negara menjadi sangat strategis untuk membumikan hukum Islam yang normatif menjadi hukum Islam yang membumi dan fungsional di tengahtengah masyarakat. Negara menjadi wasilah (instrumen), sedangkan pemberlakuan syari'at Islam adalah tujuan (ghayyah). Oleh karena itu, relasi antara agama dan negara harus bersifat integralistik dan komplementer, eksistensi negara akan berpengaruh pada eksistensi pemberlakukan syariat Islam.

\section{Analisis atas Qanun No: 14/2003 Tentang Khalwat (Mesum)}

Istilah qanun berasal dari bahasa Yunani yang diadaptasi oleh bahasa Arab melalui bahasa Suryani yang berarti alat pengukur, kemudian berarti kaidah.
Dalam bahasa Arab kata kerja qanun adalah Qanna yang artinya membuat hukum ( to make law, to legislate). Dalam perkembanganya, kata qanun berarti hukum (law), peraturan ( rule, regulation), Undang-undang (statute, code). Istilah qanun sebagai sebuah terminologi hukum sudah dipakai oleh alMawardi dalam kitabnya al-Ahkām alSultāniyah. Dalam praktiknya, pengunaan kata qanun digunakan untuk menunjukkan hukum yang berkaitan dengan masyarakat ( mu'amalat bayna alnas) bukan ibadah. ${ }^{13}$

Kata qanun dalam penggunaannya menurut Subkhi Mahmasani mempunyai tiga pengertian. Pertama, qanun adalah kumpulan peraturan hukum atau undangundang (kitab Undang-undang). Kedua, qanun berarti sama dengan kata hukum, sehingga ilmu qanun sama dengan ilmu hukum. Ketiga, qanun berarti undangundang. Pengertian qanun pada point pertama dengan qanun dalam pengertian ketiga berbeda cakupanya, karena pengertian qanun pertama lebih umum daripada qanun dalam pengertian ketiga yang hanya merujuk pada pengertian spesifik. ${ }^{14}$ Misalnya, qanun perkawinan dan qanun zakat sama pengertianya dengan undang-undang perkawinan dan undang-undang zakat.

Dalam aturan penjelasan Qanun No: 14/2003 Tentang Khalwat (Mesum) bagian Umum dinyatakan realitas praktik khalwat/mesum yang terjadi di tengah masyarakat. Dalam penjelasan qanun tersbut dinyatakan bahwa khalwat/mesum tidak hanya terjadi di tempat-tempat yang sepi dari penglihatan orang lain, tetapi juga dapat terjadi di tengah keramaian atau di jalan atau di tempat-tempat lain seperti dalam mobil atau kendaraan lainnya, di mana laki-laki dan perempuan berasyik maksyuk tanpa ikatan nikah atau hubungan mahram. Perilaku tersebut dapat menjurus kepada terjadinya perbuatan zina. Qanun tentang larangan khalwat/mesum dimaksudkan sebagai upaya pre-emtif dan preventif dan pada 
tingkat optimum remedium sebagai usaha refresif melalui penjatuhan 'uqubat dalam bentuk 'uqubat ta'zir yang dapat berupa 'uqubat cambuk dan 'uqubat denda (gharamah).

Qanun ini disahkan pada tanggal 15 Juli 2003 dan diundangkan pada tanggal 16 Juli 2003. Dalam qanun ini yang dimaksud dengan Khalwat (Mesum) adalah perbuatan bersunyi-sunyi antara dua orang mukallaf atau lebih yang berlainan jenis yang bukan muhrim atau tanpa ikatan perkawinan. Adapun cakupan perbuatan Khalwat dalam pasal 2 dijelaskan yaitu segala kegiatan, perbuatan dan keadaan yang mengarah pada perbuatan zina.

Kemudian dalam pasal 3 qanun ini menjelaskan tentang tujuan pelarangan khalwat yang meliputi lima hal. Pertama, menegakkan syari'at Islam dan adat istiadat yang berlaku dalam masyarakat di Provinsi Nanggroe Aceh Darusslam. Kedua, melindungi masyarakat dari berbagai bentuk dan atau perbuatan yang merusak kehormatan. Ketiga, mencegah anggota masyarakat sedini mungkin dari melakukan perbuatan yang mangarah kepada zina. Keempat, meningkatkan peran serta masyarakat dalam mencegah dan memberantas terjadinya perbuatan khalwat/mesum. Kelima, menutup peluang terjadinya kerusakan moral. Melakukan perbuatan khalwat/mesum adalah haram. Adapun yang menjadi sasaran pelarangan khalwat/mesum adalah setiap orang atau kelompok masyarakat, atau aparatur pemerintahan dan badan usaha yang memberikan fasilitas kemudahan dan atau melindungi orang melakukan khalwat/mesum. Dalam pasal 8 dijelaskan peran serta masyarakat dalam membantu upaya pencegahan dan pemberantasan perbuatan khalwat/mesum. Masyarakat wajib melapor kepada pejabat yang berwenang baik secara lisan maupun tulisan apabila mengetahui adanya pelanggaran terhadap perbuatan khalwat/mesum.

Dalam qanun pelarangan perbuatan khalwat/mesum ini, ancaman pidana bagi yang melanggar adalah sebagai berikut:

\begin{tabular}{|l|l|l|l|}
\hline NO & Jenis Pelanggaran & Pasal & Ketentuan Pidana / Uqubat \\
\hline 1 & $\begin{array}{l}\text { Setiap orang yang melakukan } \\
\text { perbuatan Khalwat/Mesum } \\
\text { sebagimana diatur dalam pasal } \\
4\end{array}$ & $\begin{array}{l}22 \\
\text { ayat } \\
1\end{array}$ & $\begin{array}{l}\text { Ancaman 'uqubat ta'zir } \\
\text { berupa dicambuk paling } \\
\text { tinggi 9 (sembilan) kali, } \\
\text { paling rendah 3 (tiga) kali } \\
\text { dan/atau denda paling } \\
\text { banyak Rp. 10.000.000 } \\
\text { (sepuluh juta rupiah), paling } \\
\text { sedikit Rp. 2.500.000 (dua } \\
\text { juta lima ratus rupiah) }\end{array}$ \\
\hline 2 & $\begin{array}{l}\text { Setiap orang yang melakukan } \\
\text { perbuatan Khalwat/Mesum } \\
\text { sebagimana diatur dalam pasal } \\
5\end{array}$ & $\begin{array}{l}\text { Ancaman 'uqubat Ta'zir } \\
\text { berupa kurungan paling } \\
\text { lama 6 (enam) bulan, paling } \\
\text { singkat 2 (dua) bulan } \\
\text { dan/atau denda paling } \\
\text { banyak Rp. 15.000.000 } \\
\text { (lima belas juta rupiah), } \\
\text { paling sedikit Rp. 5.000.000 } \\
\text { (lima juta rupiah). }\end{array}$ \\
\hline 3 & $\begin{array}{l}\text { Pelanggaran terhadap } \\
\text { larangan } \\
\text { dimaksud dalam pasal 5 dan 6 }\end{array}$ & $\begin{array}{l}\text { Di ancam Ta'zir } \\
\text { sebagaimana }\end{array}$ \\
\hline
\end{tabular}


'Uqūbah (pemidanaan) cambuk dilakukan oleh seorang petugas yang ditunjuk oleh jaksa Penuntut Umum. Pelaksanaan 'uqūbah dilakukan segera setelah putusan mempunyai kekuatan hukum tetap. Adapun pelaksanaan hukuman cambuk dilakukan disuatu tempat yang dapat disaksikan oleh orang banyak dengan dihadiri oleh Jaksa Penuntut Umum dan dokter yang ditunjuk. Pencambukkan dilakukan dengan rotan yang berdiameter 0.75 dampai satu (1) senti meter, panjang satu (1) meter dan tidak mempunyai ujung ganda dibelah. Pencambukkan dilakukan pada bagian tubuh kecuali kepala, muka, leher, dada, dan kemaluan.

Kadar pukulan atau cambukan tidak sampai melukai. Terhukum laki-laki dicambuk dalam posisi berdiri tanpa penyangga, tanpa diikat, dan memakai baju tipis yang menutup aurat. Sedangkan terhukum perempuan dalam posisi duduk dan ditutup kain di atasnya. Pencambukan terhadap perempuan hamil dilakukan setelah 60 (enampuluh) hari yang bersangkutan melahirkan. Apabila selama pencambukan timbul hal-hal yang membahayakan terhukum berdasarkan pendapat dokter yang ditunjuk, maka sisa cambukan ditunda sampai dengan waktu yang memungkinkan.

Adapun tujuan pemidanaan cambuk bagi pelaku khalwat/mesum dalam Penjelasan Qanun dimaksudkan sebagai upaya memberi kesadaran bagi si pelaku dan sekaligus peringatan bagi anggota masyarakat lainnya untuk tidak melakukan jarimah. Di samping itu 'uqubat cambuk akan lebih efektif dengan memberi rasa malu dan tidak menimbulkan resiko bagi keluarga. Pilihan jenis 'uqūbah dengan model cambuk, di samping untuk tujuan seperti di atas, juga dirasa lebih murah dibandingkan dengan jenis hukuman lainnya.

Ketentuan pidana pada pelangaran atas qanun khalwat bermuara pada upaya mengatur lalulintas kehidupan sosial yang terkait dengan aspek moralitas masyarakat. Target capaian yang diharapkan dari qanun tersebut adalah terciptanya tatanan moral yang berbasis pada moral Islami yang dikawal dengan instrumen regulasi melalui institusi formal yang disebut dengan Mahkamah Syari'ah. Kelompok sasaran yang terkena aturan hukum dari qanun adalah seorang muslim dan lembaga baik lembaga pemerintahan atau lembaga swasta usaha. Untuk pelanggar dari subyek hukum berupa orang, jenis hukuman pokoknya berupa cambuk di samping ada hukuman denda.

Hukuman cambuk atau dera dalam terminologi Arab adalah jild yang diderivasi dari kata jalada yang berarti memukul di kulit atau memukul dengan cambuk yang terbuat dari kulit. Hukuman cambuk sangat terasa di kulit, meskipun maksud dari hukuman ini adalah membuat terhukum malu dan mencegah orang lain untuk membuat kesalahan daripada menyakitinya. Dalam sebuah riwayat disebutkan bahwa bagian tubuh yang didera/jilid bukan hanya pada satu tempat saja, melainkan dibeberapa tempat dengan tujuan agar tidak mengakibatkan luka pada tempat tertentu saja. Bagian tubuh yang tidak boleh didera adalah bagian muka dan kemaluan.

Hukuman cambuk dinyatakan dalam al-Qur'an untuk hukuman pelaku pidana zina sebagaimana disebutkan dalam surat al-Nur ayat 2, dan qa $\dot{z} a f$ dalam surat al-Nur ayat 4, serta disebutkan dalam beberapa hadis terkait dengan hukuman bagi para peminum minuman keras. Untuk pidana zina ancaman cambukannya 100 kali, sedangkan menuduh zina ancaman pidanannya adalah 80 kali cambukan. Sedangkan hukuman para pemabuk adalah 40 cambukan. Pada masa Umar ibn Khatthab ditetapkan hukuman cambuk bagi pemabuk adalah 90 kali cambukan.

Batas hukuman cambuk untuk pidana ta'zis menurut Abu Hanifah, 
Syafi'iyyah dan Hanabilah adalah tidak boleh melebihi hukuman cambuk paling rendah yaitu 40 kali dalam hadd bagi pemabuk. Dengan demikian, batas tertinggi hukuman cambuk adalah 39 kali cambukan. Menurut Abu Yusuf, jumlah hukuman cambuk bagi pidana ta'zir boleh lebih dari 7 kali dengan ukuran batasan hukum cambuk terendah 80 kali. Sebaliknya, menurut Malikiyah tidak ada batasan hukum cambuk untuk pidana ta'zir sepenuhnya diserahkan kepada ijtihad imam. $^{15}$

Berbagai diskusi hukum terkait dengan interpretasi penerapan hukum pidana Islam telah menghiasi lembaran khazanah klasik Islam dengan keragaman pendapat hukum para ulama. Umar ibn Khatthab misalnya, ia menaikkan jumlah hadd pemabuk dari 40 cambukan yang ditetapkan Nabi menjadi 80 cambukan dengan alasan-alasan faktual-objektif yang menyebabkan perlunya penambahan jumlah cambukan $100 \%$. Hal sama juga dilakukan oleh Umar ibn Khatthab ketika tidak menghukum pencuri dengan hukuman potong tangan karena pencurian yang dilakukan pada waktu paceklik atas dorongan ekonomis yaitu mempertahankan hidup. Dengan kata lain, penerapan ketentuan normatif tekstual dalam kerangka praksisnya mengalami kelenturan-kelenturan dengan mendasarkan pada fakta-fakta hukum yang ada.

Dengan mendasarkan pada realitas empiris pemaknaan hukum pidana dan konsep pemidanaan yang memberi ruang fleksibilitas bentuk, lahirnya berbagai instrumen regulasi dalam bentuk qanun dalam bidang jinayat di NAD yang berbeda secara normatif harus diposisikan sebagai salah satu hasil ijtihad yang didasarkan atas kebutuhan lokal masyarakat Aceh. Dalam Islam tidak ada kekakuan hukum, karena hukum akan bergerak atas 'illah-nya (rasio legisnya) berdasarkan nilai kemaslahatan yang mengiringinya.
Di Malaysia, hukuman cambuk/sebat terdapat dalam empat undang-undang jinayah yaitu Undangundang Pidana, Undang-undang Persenjataan, Senjata Api dan Obat-obat berbahaya. Dalam Akta persenjataan 1960 dan akta 206, cambuk tidak kurang dari enam kali disiapkan sebagai hukuman tambahan untuk tahanan hidup, sementara untuk hukuman mati tidak dijalankan. Dalam kasus kepemilikan candu yang mempunyai bobot lebih dari dua kilogram akan dicambuk tidak kurang dari tiga pukulan.

Selanjutnya, dalam pasal 289 menggambarkan orang-orang yang tidak kena cambuk dalam hal ini adalah: (a) wanita, (b) orang lelaki yang telah dikenakan hukuman mati, (c) orangorang lelaki yang oleh pengadilan telah mengakui berusia lebih dari lima puluh tahun. Dalam pelaksanaan hukuman, hukuman cambuk tidak akan dilaksanakan kecuali ada surat dari dokter yang menyatakan bahwa tertuduh berada dalam kesehatan yang sangat baik untuk dilaksanakan hukuman. Malaysia juga menerapkan hukuman cambuk kepada pendatang asing yang tidak memiliki dokumen yang sah, 16

Di Pakistan, pengaturan hukuman dalam bentuk cambuk tertuang dalam Ordonansi nomor IX tahun 1979 Republik Islam Pakistan. Pelaksanaan hukuman cambuk di Pakistan juga mensyaratkan hal-hal sebagai berikut; (a) pengecekan kesehatan terpidana, (b) jika terpidana terlalu tua atau terlalu lemah, maka jumlah sebatan dilaksanakan dengan cara interval, (c) jika terpidana dalam keadaan sakit eksekusi hukuman ditunda, (d) jika terpidana adalah wanita hamil, maka pelaksanaan hukuman cambuk dilaksanakan 2 bulan setelah melahirkan, (e) kalau pada saat eksekusi hukuman, cuaca terlalu dingin atau terlalu panas, eksekusi dapat ditinda sampai cuaca menjadi normal, (f) hukuman dapat dilaksanakan dengan kehadiran pihak medikal. ${ }^{17}$ 
Penerapan hukuman jināyah yang berbeda dalam pengaturan jenis pelanggaran dan bentuk hukuman di beberapa negara Islam memperlihatkan adanya dinamika dan fleksibilitas penerapan hukum jināyah Islam. Oleh karena itu, kerja-kerja intelektual untuk merumuskan ketentuan normatif hukum pidana Islam dalam kerangka praksis menjadi tantangan ummat Islam. Membaca pendapat umum masyarakat dan pertimbangan-pertimbangan nilainilai lokal harus menjadi bahan pertimbangan dalam merekonstruksi hukum pidana Islam.

Islam meyakini perubahan sebagai suatu realitas yang tidak bisa diingkari. Islam juga memberi posisi yang paling tepat demi memudahkan semua hal untuk berubah secara sahih dan aman. Agama berjalan bersama beriringan dengan lajunya kehidupan. Tugas agama adalah mengawal perubahan secara benar untuk kemaslahatan hidup manusia ${ }^{18}$ Di sinilah sesungguhnya tugas seorang cendekiawan muslim untuk merumuskan pendekatan dan metodologi yang tepat sesuai dengan konteks yang melingkupinya agar agama menjadi fungsional dan bisa membumi. Dalam hukum Islam, perubahan sosial budaya dan letak geografis menjadi variabel penting yang ikut mempengaruhi adanya perubahan hukum. Ibnu Qayyim alJauziyah menyatakan, bahwa "perubahan fatwa adalah dikarenakan perubahan zaman, tempat, keadaan dan kebiasaan." 19 Dalam kaidah fikih lainnya disebutkan "hukum itu berputar bersama illah-nya (alasan hukum) dalam mewujudkan dan meniadakan hukum ",20.

Kaidah fikih di atas memberikan landasan bagi pengembangan hukum Islam dengan wawasan multikultural. Variabel waktu (time), tempat (space) dan tradisi (culture) merupakan tiga faktor pembentuk hukum yang bertumpu pada dimensi historisitas yang berwatak dinamis. Lahirnya berbagai mazhab hukum (fikih) dalam rentang sejarah pemikiran hukum Islam dengan corak dan watak yang berbeda-beda membuktikan watak fikih yang dinamis dan selalu beradaptasi dengan pluralitas budaya lokal di mana pemikiran hukum itu lahir.

Salah satu bukti konkrit betapa faktor lingkungan sosial budaya berpengaruh terhadap hukum Islam adalah munculnya dua pendapat Imam Syafi'i yang dikenal dengan qawl alqādim dan qawl al-jadid. Pendapat lama (qawl qadim) adalah pendapat hukum Imam Syafi'i ketika beliau berada di Baghdad, sedangkan qawl al-jadid ketika beliau tinggal di Mesir. ${ }^{21}$ Perbedaan pendapat hukum dalam masalah yang sama dari seorang Mujtahid Imam Syafi'i jelas disebabkan faktor struktur sosial, budaya, letak geografis yang berada antara daerah Iraq (Baghdad) dan Mesir.

Dalam konteks historis, pemikiran bidang hukum Islam sesungguhnya memperlihatkan kekuatan yang dinamis dan kreatif dalam mengantisipasi setiap perubahan dan persoalan-persoalan baru. Hal ini dapat di lihat dari munculnya sejumlah mazhab hukum yang memiliki corak sendiri-sendiri sesuai dengan latar belakang sisio-kultural dan politik di mana mazhab itu tumbuh dan berkembang. Warisan monumental yang sampai sekarang masih memperlihatkan akurasi dan relevansinya adalah kerangka metodologi penggalian hukum yang mereka ciptakan. Dengan perangkat metodologi tersebut, segala permasalahan bisa didekati dan dicari legalitas hukumnya dengan metode qiyas, maslahah al-mursalah, istihsān, istiṣ̆āb dan 'urf ${ }^{22}$. Dalam posisi demikian, hukum Islam akan berfungsi sebagai rekayasa sosial (social engineering) untuk melakukan perubahan dalam masyarakat.

Untuk menempatkan hukum pada posisi yang betul-betul fungsional dalam menghadapi setiap perubahan sosial, diperlukan terobosan metodologis disertai kemampuan membaca fenomena zaman. 
Banyak perangkat ilmu bantu yang bisa menopang perumusan hukum menjadi aplikatif, seperti ilmu-ilmu tafsir, tarikh dan ilmu tata bahasa Arab. Diharapkan melalui pendekatan konvergensi antara ilmu ushul fiqh dan ilmu-ilmu lainnya akan dapat mengurangi formalisme hukum Islam.

Dalam konteks ini, pemaknaan hukum Islam tidak harus dilihat dari perspektif nilai saja, tetapi perlu di cari keterkaitan secara organik dan struktural dalam kehidupan sosial. Di sinilah letak pentingnya fenomena transformasi pemikiran hukum Islam, tidak hanya dilihat sebagai fenomena keagamaan saja. Transformasi pemikiran hukum Islam di Indonesia merupakan suatu pergumulan kreatif antara Islam dengan masyarakat Indonesia, antara nilai-nilai Islam dengan kenyataan struktural masyarakat. Oleh karena itu, maka program pembaruan pemikiran hukum Islam adalah suatu bagian yang tidak terpisahkan dari proses kehidupan masyarakat yang selalu berubah.

Akan tetapi, untuk melakukan upaya pembaruan pemikiran hukum Islam (fikih) khususnya bidang hukum pidana (fikih jinăyah) diperlukan beberapa syarat; pertama, adanya tingkat pendidikan yang tinggi dan keterbukaan dari masyarakat muslim, kedua, hukum Islam (fikih) harus dipandang sebagai suatu yang bersifat partikular yang selalu dibatasi oleh dimensi ruang dan waktu, ketiga, memahami faktor sosio-kultural dan setting politik yang melatarbelakangi lahirnya suatu produk hukum agar dapat memahami partikularisme dari pemikiran hukum tersebut, keempat, mengorientasikan istinbat hukum dari aspek qaulan (materi hukum) kepada aspek manhajan (kerangka metodologis). Di samping itu, perlu juga memahami pemikiran hukum yang tidak dibatasi sekat-sekat mazhab.

Penerapan hukuman jinayah yang berbeda dalam pengaturan jenis pelanggaran dan bentuk hukuman di beberapa negara Islam memperlihatkan adanya dinamika dan fleksibilitas penerapan hukum jināyah Islam. Oleh karena itu, kerja-kerja intelektual untuk merumuskan ketentuan normatif hukum pidana Islam dalam kerangka praksis menjadi tantangan ummat Islam. Membaca pendapat umum masyarakat dan pertimbangan-pertimbangan nilainilai lokal harus menjadi bahan pertimbangan dalam merekonstruksi hukum pidana Islam.

\section{Penutup}

Gagasan formalisasi syari'at tidak bisa dipisahkan dari adanya krisis konstitusi dalam mengakomodir tuntutan masyarakat lokal seperti Daerah Nangroe Aceh Darussalam (NAD). Penerapan syari'at Islam di Nangroe Aceh Darussalam dalam bentuk regulasi baik dalam bentuk Undang-undang, Peraturan Daerah atau Qanun adalah bagian dari ijtihad sebagai ikhtiar pemberlakuan hukum Islam dalam sistem hukum nasional sebagai upaya penerapan syari'at Islam secara käffah yang dilakukan secara legal dan konstitusional. Pelaksanaan syari'at Islam di Nanggroe Aceh Darussalam merupakan refleksi dari aspirasi mayoritas rakyat Aceh.

Lahirnya qanun Khalwat bermuara pada tujuan hukum yaitu terciptanya tatanan moral yang berbasis pada moral Islami yang dikawal melalui instrumen regulasi melalui institusi formal yang disebut dengan Mahkamah Syari'ah. Qanun Khalwat sebagai hukum materiil khususnya dalam bidang hukum pidana, dalam banyak hal adalah hasil ijtihad hukum yang ingin memadukan berbagai ketentuan hukum Islam yang bersumber dari al-Qur'an dan Hadis serta pendapat ulama fikih dengan tuntutan lokal masyarakat Aceh. Konsekuensinya adalah berbagai qanun pidana yang lahir di Aceh memiliki derajat keragaman bahkan ada disparitas konsep fikih dengan dengan ketentuan-ketentuan hukum dalam qanun. 


\section{Catatan Akhir:}

${ }^{1}$ Abdul Halim, Politik Hukum Islam di Indonesia (Jakarta: Ciputat Press, 2005), hlm. 178.

${ }^{2}$ Mahmud Al-Anshori, Penegakan Syari'at Islam Dilema Keummatan di Indonesia (Jakarta: Inisiasi Press, 2005), hlm. 24-25.

${ }^{3}$ Yusdani, "Formalisasi Syari'at Islam dan Hak Asasi Manusia di Indonesia", Jurnal AlMawarid, Edisi XVI Tahun 2006, hlm. 192-193.

${ }^{4}$ Dalam pandangan Al-Yasa Abu Bakar, Ketua Dinas Syariat Islam Provinsi NAD menyatakan bahwa era reformasi telah membuka ruang terjadinya keragaman adat dan budaya serta keragaman pemerintahan lokal Indonesia dan peluang ini bagi masyarakat Aceh ditangkap sebagai pintu masuk bagi pemberlakuan syariat Islam dalam semua sendi kehidupan. Lihat AlYasa Abu Bakar, "Islam, Hukum dan Masyarakat di Aceh, Tajdid Syari'at Dalam Negara Bangsa", Makalah First International Conference of Aceh and Indian Ocean Studies, 24 - 27 Februari 2007.

${ }^{5}$ Taufik Adnan Amal dan Samsu Rizal Panggabean, Politik Syariat Islam Dari Indonesia Hingga Nigeria (Jakarta: Pustaka Alvabet, 2004), hlm. 26-27. Lihat juga, Qanun Provinsi Nangroe Aceh Darussalam No. 12 Tahun 2003 Tentang Minuman Khamar dan Sejenisnya Lembaran Daerah Provinsi Nagroe Aceh Darussalam Tahun 2003 Nomor 25 Seri D Nomor 12. Qanun Provinsi Nangroe Aceh Darussalam No. 13 Tahun 2003 Tentang Maisir (Perjudian) Lembaran Daerah Provinsi Nagroe Aceh Darussalam Tahun 2003 Nomor 26 Seri D Nomor 13. Qanun Provinsi Nangroe Aceh Darussalam No. 14 Tahun 2003 Tentang Khalwat (Mesum) Lembaran Daerah Provinsi Nangroe Aceh Darussalam Tahun 2003 Nomor 27 Seri D Nomor 14.

${ }^{6}$ Abi Hasan al-Mawardi mendefinisikan

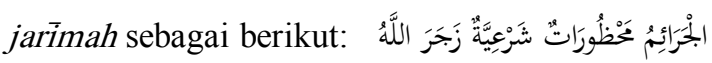
lihat. Al-Mawardi. Kitāb alAhkām al-Sultāniyyah (Bairūt: Dār al-Fikr, 1967), hlm. 438.

${ }^{7}$ Kata hudūdadalah bentuk jamak dari kata hadd yang berarti pencegahan, penekanan atau larangan. Dalam hukum Islam kata hudüd dibatasi untuk hukuman karena melakukan tindak pidana yang disebutkan oleh al-Qur'an atau Sunnah Nabi. Sedangkan hukuman lain yang ditetapkan berdasarkan pertimbangan hakim disebut $t a^{\prime} z \bar{i} \dot{r}$. $T a^{\prime} z \overline{i r}$ secara bahasa adalah membinasakan pelaku kriminal karena melakukan tindak pidana yang memalukan atas dasar pertimbangan hukum hakim. Kata lain untuk menunjukan hukuman adalah 'uqūbah yang berasal dari kata 'uqb berarti sesuatu yang datang setelah sesuatu yang lainya. Lihat, Abdurahman I Doi. Syari'ah The Islamic law, terj. Zaimuddin dan Rusydi Sulaiman, Hudud Dan Kewarisan (Syari'ah II) (Jakarta: PT RajaGrafindo Persada, 1996), hlm. 6-7. Bandingkan dengan, Muhammad Said alAsymawi, Problematika dan Penerapan Syari'at Islam dalam Undang-undang, terj. Saiful Ibad, (Jakarta: Gaung Persada Press, 2005), hlm. 117. Bandingkan pula dengan, Abu Sahl al-Syarakhsi, Al-Mabsüt (Beirut: Dār al-Ma'rifah, 1406 H) X: 478.

${ }^{8}$ Muhammad ibn Ism̄àil al-Șan'ānì, 1379 H, Subul al-Salām (Bairūt: Dār al-Ikhyā' alTuräs, tt.), V: 270. Bandingkan pula dengan Abd al-Qadir Audāh, Al-Tasyri' al-Jinā'i fi al-Islām, (Bairūt: Dār al-Ihyā al-Turās, tt.) I: 139.

${ }^{9}$ Amal dan Panggabean, Politik Syari'at Islam, hlm. 25-27.

${ }^{10}$ Rifyal Ka'bah, Penegakan Syari'at Islam di Indonesia (Jakarta: Khoirul Bayan, 2004), hlm. 20-25.

11 A. Rahmat Rosyadi dan Rais Ahmad, Formalisasi Syari'at Islam dalam Perspektif Tata Hukum Indonesia (Jakarta: Ghalia Indonesia, 2006), hlm. 169

${ }^{12}$ Ka'bah, Penegakan, hlm. 42.

13 A. Qodri Azizy, Eklektisisme Hukum Nasional: Kompetisi antara Hukum Islam dan Hukum Umum (Jogjakarta: Gama Media, 2004), hlm. 57-58.

14 Subhi Mahmassani, Filsafat Hukum Dalam Islam, terj. Ahmad Sudjono (Bandung: PT al-Maarif, 1976), hlm. 27-28.

${ }^{15}$ Rusjdi Ali Muhammad, Revitalisasi Syari'at Islam di Aceh: Problem, Solusi dan Implementasi (Jakarta: Logos dan Ar-Raniry Press, 2003), hlm.109-113.

${ }^{16}$ Ibid., hlm. 114-117.

${ }^{17}$ Ibid., hlm. 119-120.

18 Abdul Halim Uways, Fiqh Statis Dinamis (Bandung: Pustaka Hidayah, 1998), hlm. 221.

19 Ibn Qayyim al-Jawziyah, I'lām alMuawaqqi' in 'an Rabb al-'Alamīn (Bairūt: Dār al-Fikr, tt.), hlm. 14.

20 Mukhtar Yahya dan Fathurrahman, Dasar-Dasar Pembinaan Hukum Fiqh Islam (Bandung: PT Al-Ma'arif, 1996), hlm.550.

21 M. Atho' Mudzhar, Membaca Gelombang Ijtihad antara Tradisi dan Liberasi (Jogjakarta: Titian Ilahi Press, 1998), hlm. 107.

${ }^{22}$ Syamsul Arifin Dkk., Spiritualisasi Islam dan Peradaban Masa Depan (Jogjakarta: Sipress, 1996), hlm. 72-73. Adapun penjelasan perangkat metodologi Ijtihad/istinbat di atas adalah sebagai berikut. Qiyas adalah menyamakan suatu peristiwa hukum yang tidak ada nashnya dengan peristiwa hukum yang terdapat nash yang mengaturnya karena adanya persamaan illah (sebab) hukum antara keduanya. Maslahah al- 
Mursalah adalah suatu kemaslahatan yang terlepas yaitu kemaslahatan yang oleh agama tidak diperintah tetapi juga tidak dilarang/ditolak. Istihsān adalah berpalingnya seorang mujtahid dari qiyas jaly ke qiyas khafi atau berpalingnya seorang mujtahid dari hukum kulli ke hukum juz'i. Istishab mengukuhkan atau menganggap tetap berlaku hukum yang pernah ada sampai diperoleh dalil lain yang mengubahnya. Urf/'Adat adalah apa-apa yang dibiasakan atau diikuti oleh orang banyak dan lakukan berulang-ulang dan diterima baik oleh akal mereka.

\section{DAFTAR PUSTAKA}

Abu Bakar, Al-Yasa. "Islam, Hukum dan Masyarakat di Aceh, Tajdid Syari'at Dalam Negara Bangsa", Makalah First International Conference of Aceh and Indian Ocean Studies, 24 - 27 Februari 2007.

Adnan Amal, Taufik dan Panggabean, Samsu Rizal. Politik Syariat Islam Dari Indonesia hingga Nigeria. Jakarta: Pustaka Alvabet, 2004.

Al-Anshori, Mahmud. Penegakan Syari'at Islam Dilema Keummatan di Indonesia. Jakarta: Inisiasi Press, 2005.

Al-Asymawi, Muhammad Said. Problematika dan Penerapan Syari'at Islam dalam Undangundang, terj. Saiful Ibad. Jakarta: Gaung Persada Press, 2005.

Arifin, Syamsul. Spiritualisasi Islam dan Peradaban Masa Depan. Jogjakarta: Sipress, 1996.

Awdāh, Abd al-Qadir. Al-Tasyri' alJinā'i fí al-Islām. Bairūt: Dār alIhyā al-Turās, T.t.

Azizy, A. Qodri. Eklektisisme Hukum Nasional: Kompetisi antara Hukum Islam dan Hukum Umum. Jogjakarta: Gama Media, 2004.

Halim, Abdul. Politik Hukum Islam di Indonesia. Jakarta: Ciputat Press, 2005.

I Doi, Abdurahman. Hudud Dan Kewarisan (Syari'ah II), terj. Zaimuddin dan Rusydi Sulaiman.
Jakarta: PT RajaGrafindo Persada, 1996.

Al-Jawziyah, Ibn Qayyim. I'lām alMuawaqqi'in 'an Rabbi al'Alamīn. Bairüt: Dār al-Fikr, T.t.

Ka'bah, Rifyal. Penegakan Syari'at Islam di Indonesia. Jakarta: Khoirul Bayan, 2004.

Mahmassani, Subhi. Filsafat Hukum Dalam Islam, terj. Ahmad Sudjono. Bandung: PT al-Maarif, 1976.

Al-Māwardi, Abu Hasan. Kitāb alAḥkām al-Sultāniyah. Bairūt: Dār al-Fikr, 1967.

Al-Ṣan'āni, Muhammad ibn Ismāil. Subul al-Salām. Bairūt: Dār al-Ikhyā alTuräs, $1379 \mathrm{H}$.

Al-Syarakhsi, Abu Sahl. Al-Mabsüt. Beirut: Dār al-Ma'rifah, 1406 H.

Mudzhar, M. Atho'. Membaca Gelombang Ijtihad antara Tradisi dan Liberasi. Jogjakarta: Titian Ilahi Press, 1998.

Qanun Provinsi Nangroe Aceh Darussalam No. 14 Tahun 2003 Tentang Khalwat (Mesum) Lembaran Daerah Provinsi Nagroe Aceh Darussalam Tahun 2003 Nomor 27 Seri D Nomor 14.

Rosyadi, A. Rahmat dan Rais Ahmad. Formalisasi Syari'at Islam dalam Perspektif Tata Hukum Indonesia. Jakarta: Ghalia Indonesia, 2006.

Uways, Abdul Halim. Fiqh Statis Dinamis. Bandung: Pustaka Hidayah, 1998.

Yahya, Mukhtar dan Fathurrahman. Dasar-dasar Pembinaan Hukum Fiqh Islam. Bandung: PT AlMa'arif, 1996.

Yusdani, "Formalisasi Syari'at Islam dan Hak Asasi Manusia di Indonesia", Jurnal Al-Mawarid, Edisi XVI Tahun 2006. 